\title{
Reagent Technology of Joint Purification of Sewage Water for Paint and Galvanic Production
}

\author{
Anatoli Hurynovich ${ }^{1 *}$, Uladzimir Maroz ${ }^{2}$ \\ 1 Faculty of Civil and Environmental Engineering, Bialystok University of Technology, ul. Wiejska 45A, \\ 15-351 Bialystok, Poland \\ 2 Faculty of Environmental Engineering Brest State Technical University, Moskowskaja 265, 224017 Brest, \\ Belarus \\ * Corresponding author's e-mail: a.gurinowicz@pb.edu.pl
}

\begin{abstract}
There is a need to create a low-cost and effective resource-saving technology for wastewater treatment contaminated with paintwork materials, which would allow reusing water in the production cycle of the enterprise. Studies have been carried out to prove the possibility of using spent technological solutions in the joint purification of sewage from galvanic and paint and varnish industries. The developed technology enables to reduce the costs of the enterprises for its cleaning and negative impact on the environment, reduce the load on urban treatment facilities, and reduce the equipment costs.
\end{abstract}

Keywords: paintwork materials, waste technological solutions, mixer, reactor, sorption, flocculation, sewage, galvanic production, paint and varnish production.

\section{INTRODUCTION}

The enterprises of mechanical engineering, as a rule, besides galvanic manufactures and production of printed circuit boards also include the manufacturing of paints . Various organic substances (acids, alkalis, solvents, surfactans) found in the wastewater of paint industries constitute extremely dangerous pollutants. These substances are characterized by a complex and variable composition, high toxicity, the predominant content of dissolved, rather than suspended substances. Therefore, their isolation is a task of extreme complexity. The famous methods of cleaning of such kind of waste water (ultrafiltration, combustion, ion exchange, etc.) are associated with very high energy costs, high cost of technological equipment, shortage of reagents and the need for significant production areas [Gogina et al., 2012].

The purpose of the work is the creation of an effective resource-saving technology for joint wastewater treatment of paint and varnish and galvanic production [Maroz, 2013].
The research was conducted aimed at creating an effective resource-saving technology for the purification of such wastewater, which would allow not only to clean up the waste water of paint and varnish production to the required standards, but also to reuse a significant part of them [Grinin 2002].

The survey of water supply and sewage systems of paint and varnish production showed that the painting of large products is carried out, as a rule, by the method of pneumatic spraying. At the same time, only $45-75 \%$ of the paint is applied to the surface of the products, and the rest is discharged with sewage.

In addition, these production problems create problems in wastewater treatment due to the presence of heavy metals in them, which enter sewage during the preparation for painting the surface of products, as well as when discharging contaminated water from the hydrofilters of the paint and varnish chambers shown in Figure 1.

When painting products, the water in the hydrofilter constantly circulates according to the 


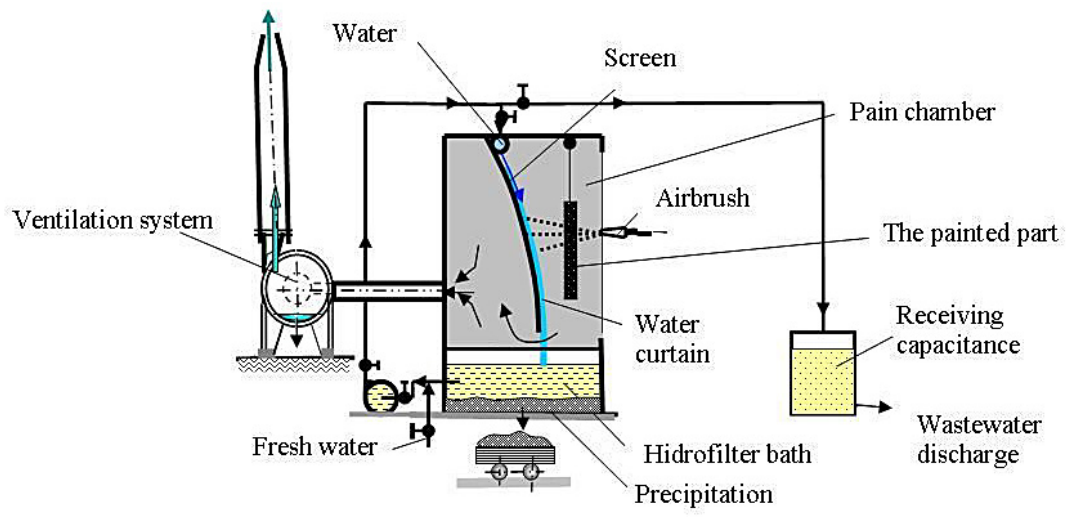

Figure 1. Paint by pneumatic spraying using a hydrofilter

scheme: a water curtain - a hydrofilter bath $-\mathrm{a}$ pumping unit - a water curtain. Upon contact with water of paint and varnish material, a partial dissolution of the chemicals entering into its composition occurs, the concentration of which in the water curtain increases with each cycle. After reaching the maximum permissible concentration of pollutants in the water of the hydrofilter bath, the water curtain loses its retention properties.

Therefore, such water from the hydrofilter bath and the formed bottom deposits of paint and varnish are removed; afterwards, the hydrofilter bath is replenished with fresh water. The air cleared of toxic aerosols by means of ventilating systems is taken away into the atmosphere [Subotkin 2017].

\section{METHODS OF RESEARCH}

In order to develop a technology for joint cleaning of wastewater paint and galvanic industries:

- production processes of paint and varnish and galvanic industries were investigated;

- the qualitative and quantitative composition of waste technological solutions was studied for the purpose of their use in the process of wastewater treatment;

- the rational formation of sewage streams of galvanic and paint and varnish production at the places of their formation;

- the kinetics of aggregation and sorption of paint and varnish material on oxyhydrate reservoirs in a mixture of wastewater of paint and varnish and galvanic production is investigated; hydrodynamic processes in laboratory and production conditions were studied;

- automated reactor units were developed.
Studies pertaining to the dynamics of flocculation and sorption of paint and varnish material on the oxyhydrate collectors under certain conditions were carried out on a laboratory installation.

In a reactor with the volume of $\mathrm{V}=10 \mathrm{dm}^{3}$ the wastewater of the paint and galvanic production is mixed with a stirrer for 10 minutes and then settled in a graduated cylinder for 30 minutes. The $\mathrm{pH}$ value is controlled by an ion meter.

At the first stage, the hydrolysis of the salts of metals $\mathrm{Cr}$ (III) occurs, $\mathrm{Fe}$ (III) and others, with the formation of micelles and their subsequent aggregation into larger particles of the sol. At the second stage, the construction of chain structures begins and the formation of a huge number of tiny flakes, which are aggregated into larger ones, and, reaching a certain size, they settle down under the action of gravity.

With prolonged mechanical mixing, the flocs formed are destroyed, which as a result of the reduction in their hydraulic size do not settle well. The experimental setup was shown in Figure 2.

In order to assess the reliability of these hydrodynamic processes in an actual apparatus and to reduce the uncertainty that inevitably arises in large-scale transfer of results, studies were carried out in the laboratory setup shown in Figure 3.

The installation consists of a propeller-mixer apparatus, driven with a direct current electric motor (12 volts). The speed of the mixer shaft is recorded by a tachometer. The water in the device is fed by a pump from the tank. The flow rate is regulated by a valve mounted on the pressure line, and is measured by a rotameter. The electrical conductivity of the solution is determined using a conductometer and fixed on the recorder. The used solution was drained into the sewage system. Distilled water was used as a working liquid, whereas potassium chloride $(\mathrm{KCl})$ is an indicator. The liquid was fed into the mixing area. 


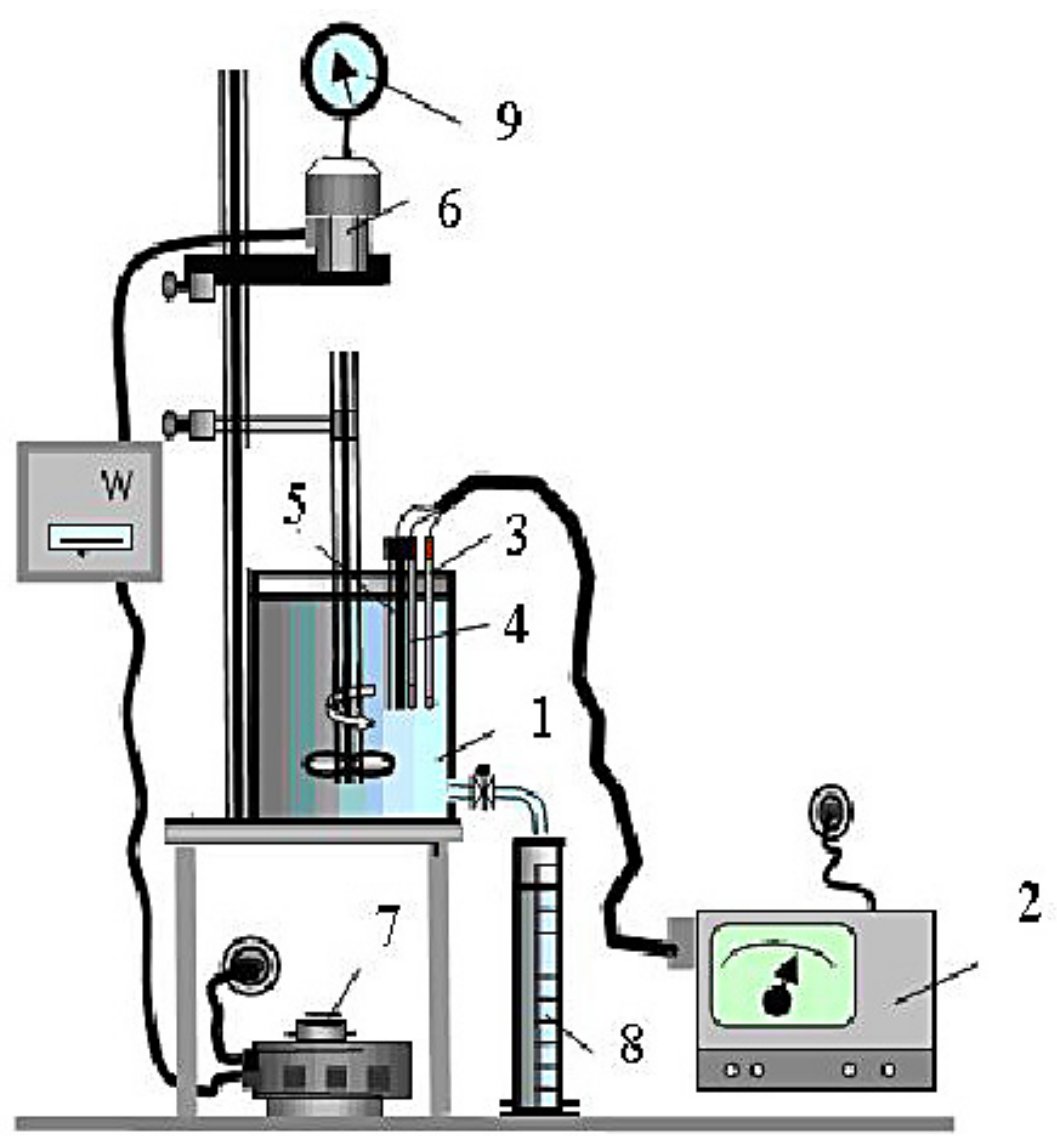

Figure 2. Experimental setup

1 - reactor; 2 - ion meter 3 - measuring electrode; 4 - reference electrode; 5 - thermal compensation electrode; 6 - mixer; 7 - transformer: 8 - measuring cylinder;

9 - tachometer; 10 - wattmeter

The structure of the flows was investigated by analyzing the response of the system to a perturbation [Tishin, 2002; Vinogradov, 2002]. Before the beginning of the experiment, the apparatus was filled with distilled water to the required level, including a stirrer. An indicator was inserted into the apparatus.

At the entrance to the apparatus, an indicator ( $\mathrm{KCl}$ solution) was introduced, the time of entry being taken as the beginning of the experiment, and a corresponding mark was made on the instrument diagram.

During the experiment, a constant flow of water and the speed of the mixer were maintained. The electrical conductivity was measured continuously during the experiment; the experiment was terminated when the value of electrical conductivity became equal to the electrical conductivity of distilled water.

The obtained response curves in relative coordinates are shown in Figure 4.

\section{RESULTS OF RESEARCH}

The analysis of the results obtained from the studies showed that the response curves taken at different fluid flows and different mixer speeds (190-300 rpm) corresponding to the revolutions of the mixers of standard chemical devices are identical, i.e., the structure of the flows in the apparatus in this range of mixer speeds practically does not depend on the speed of rotation of the mixer and the flow rate of the fluid. The structure of the flows is close to the ideal mixing model and a similar apparatus can be referred to a reactor-mixer.

For the chosen geometry of the apparatus, in the investigated range of fluid flow rate and rotational speed of the mixer, the hydrodynamic situation in the laboratory apparatus corresponds to the conditions of ideal mixing and is described with sufficient accuracy by the ideal mixing model.

When used instead of the purchased reagents, waste metal solutions containing high $F e$ (II) and 


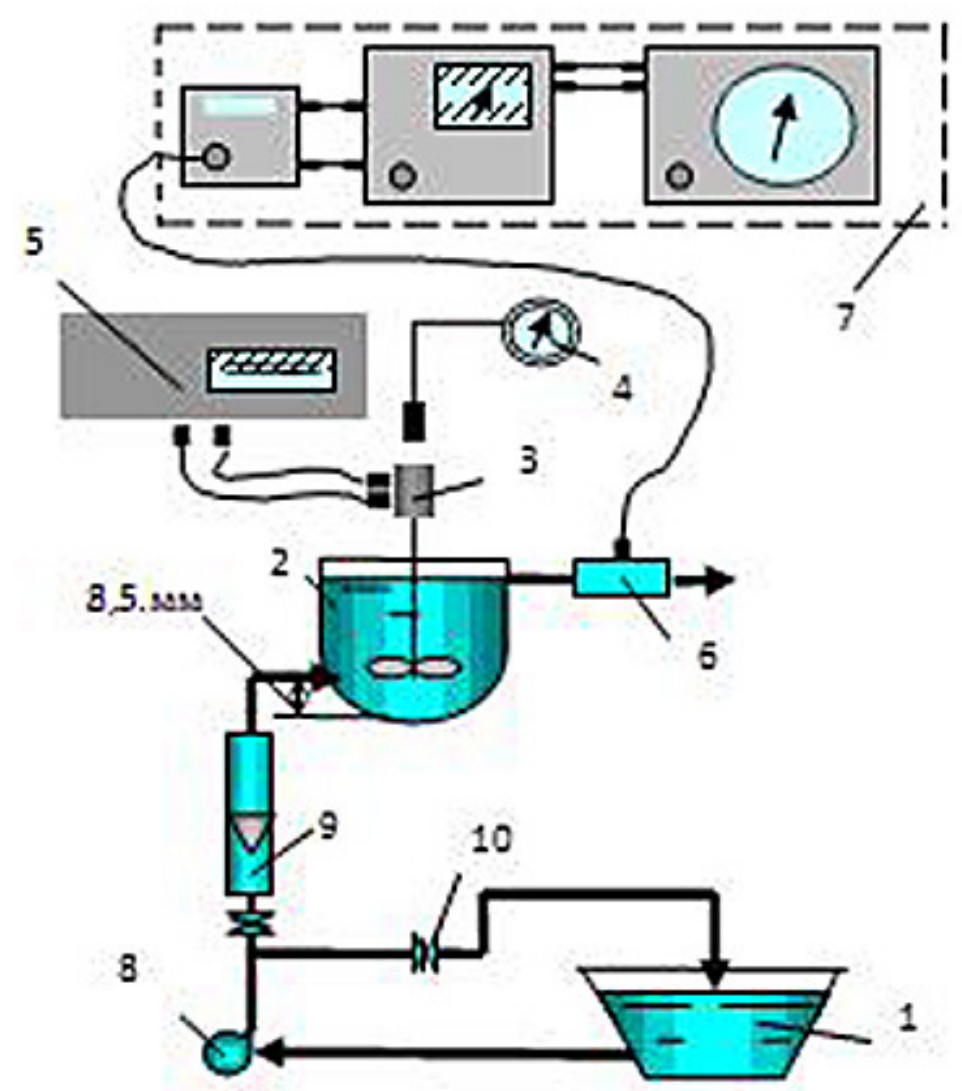

Figure 3. Diagram of an experimental laboratory installation for studying the structure of flows in apparatus equipped with mechanical stirrers

1 - distilled water; 2 - mixer; 3 - electric motor; 4 - tachometer; 5 - speed control system for mixers; 6 - conductometric cell; 7 - conductivity measuring system; 8 - pump; 9 - rotameter; 10 - valves
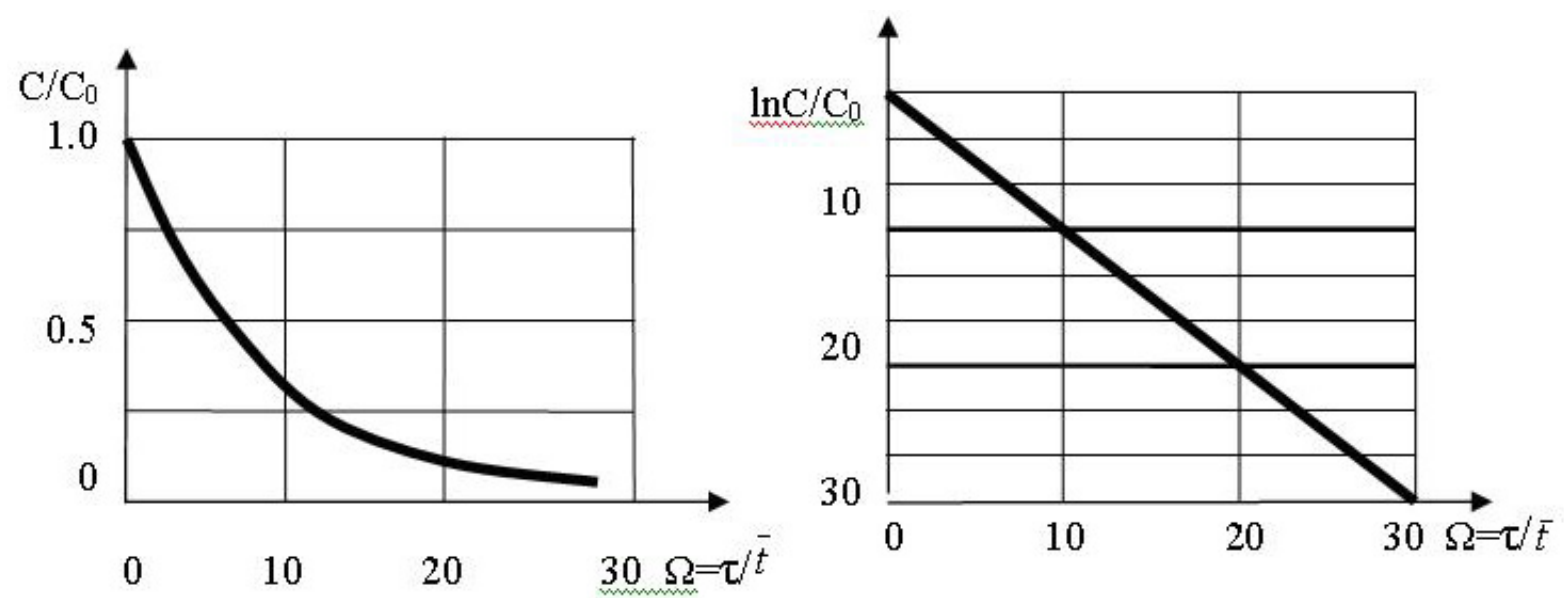

Figure 4. Response curves in relative coordinates

$\mathrm{Fe}$ (III) (Fe (III) concentrations of more than $20 \mathrm{~g} / \mathrm{dm}^{3}$ for $C r(V I)$ reduction up to $\mathrm{Cr}(I I I)$, the standard system for automatic control of the $\mathrm{Cr}$ (VI) reduction process proved to be ineffective. This was due to the fact that the sensitive element of the chromium indicator with the $\mathrm{Fe}$ (III) content of more than $5 \mathrm{mg} / \mathrm{dm}^{3}$ was ineffective.
The laboratory investigations were carried out to find a technical solution that would exclude the effect of $\mathrm{Fe}$ (III) ions on the sensitive element of the chromium indicator and allow automatic control of the redox potential. In order to eliminate the "interfering background", the ability of $\mathrm{Fe}$ (III) ions to form stable complex ions with 
certain compounds was used. At the same time, the degree of influence of the "interfering background" on the sensitive element of the automatic control system by the reduction process $\mathrm{Cr}(V I)$ to $\mathrm{Cr}$ (III) was refined by laboratory studies.

Complexing reagents were introduced into the sample taken from the reactor for processing the sewage mixture containing the paint and chromium, which react readily with $\mathrm{Fe}$ (III) ions in aqueous solutions.

It can be seen from Figure 5 that the signaling device for the presence of $\mathrm{Cr}(\mathrm{VI})$, and consequently the entire automatic control system, becomes operative when a complexing agent is introduced into the reaction medium. When adding a reducing agent to the solution, which is necessary for complete recovery, a sharp potential jump occurs.

Complex formation, causing a change in the concentration of free ions in the oxidized form, causes a change in the redox potential of the system and selectively removes the influence of the "interfering" background in the work of the chromium meter. This feature eliminated the difficulties that arose, but did not solve the problem of the location of the complexing reagent into the technological scheme. If a masking complexing reagent were introduced directly into the medium to be treated, it would require a large number and additional equipment for preparing the working solution.

As a result of the reaction, the $F e$ (III) ions are bound to the complex, i.e., the "interfering background" is eliminated. In the case of the chromates appearance in the detoxified water, an electromotive force appears on the electrodes of the sensing element, which is amplified by the transducer. The amplified signal is fed to the control unit, where it is controlled by a pneumatic valve. As a result, a working reagent that reduces $\mathrm{Cr}(I V)$ is added to the main reactor from the dispenser. After the complete reduction of $\mathrm{Cr}(\mathrm{IV})$, the pneumatic valve closes.

With the use of advanced standard automatic control systems, it became possible to rationally use the created "disturbing background" of spent technological solutions instead of purchased reagents. The studies were conducted on the stageby-stage treatment of wastewater containing paint and varnish material [Maroz, 2014]. At the first stage, bubbling of wastewater containing LMC was carried out for 20 minutes. At the same time, the value of COD decreased by $20 \%$ (Figure 6).

In the second stage, as a result of oxidation of organic contaminants in a mixture of wastewater containing paint and chrome, within 10 minutes, the COD value decreased by another $25 \%$ (Figure 7).

At the third stage, after neutralization of all types of wastewater and formation of an oxyhydrate collector sorbing organic and mineral impurities on its surface, followed by clarification in the sedimentation tank, the COD decreased to $25 \mathrm{mg} \mathrm{O}_{2} / \mathrm{dm}^{3}$ (Figure 8).

The technology is implemented as follows. Wastewater containing paint and varnish contamination is sent to a reservoir in which a purge of sewage with compressed air is carried out for at least 20 minutes with a stirring intensity of $3-51 /\left(\mathrm{s}-\mathrm{m}^{2}\right)$. Afterwards, the treated wastewater containing paint-and-lacquer material is dosed to the tank, together with the wastewater containing chromium and acidic wastewater containing the

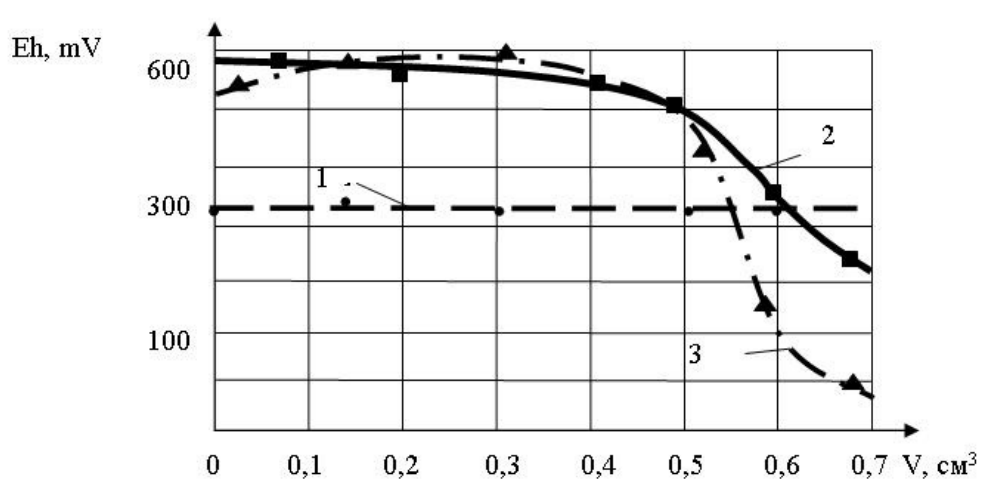

Figure 5. The graph of the change in the oxidation-reduction potential Eh in the process of reduction of $\mathrm{Cr}(\mathrm{VI})$ by the spent pickling solution containing $\mathrm{Fe}$ (II) and $\mathrm{Fe}$ (III)

1 - without complexing agent; 2 - with addition of complexing agent "A"; 3 - with the addition of complexing agent "B" 
COD,

$\mathrm{Mg} \mathrm{O}_{2} / \mathrm{dm}^{3}$

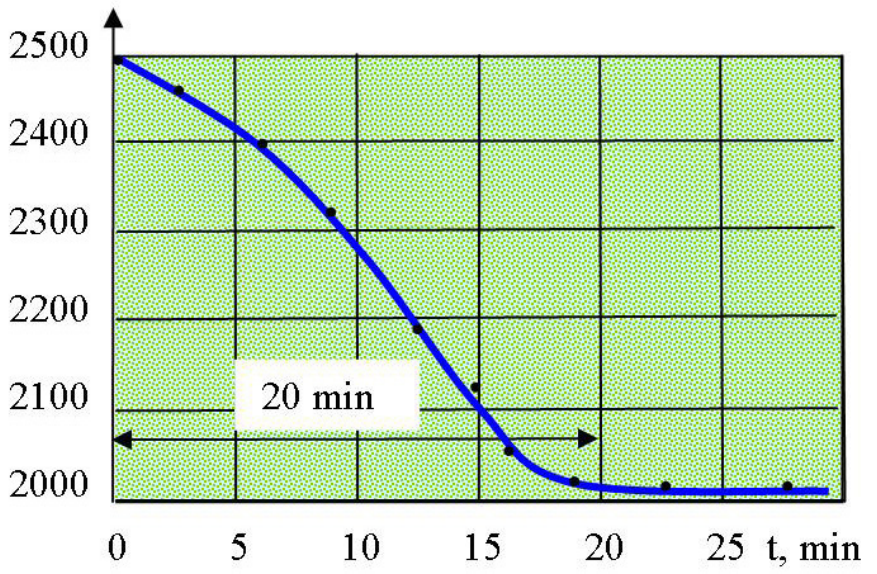

Figure 6. Schedule of COD reduction by bubbling compressed air (1st stage)

COD,

$\mathrm{Mg} \mathrm{O} / \mathrm{dm}^{3}$,

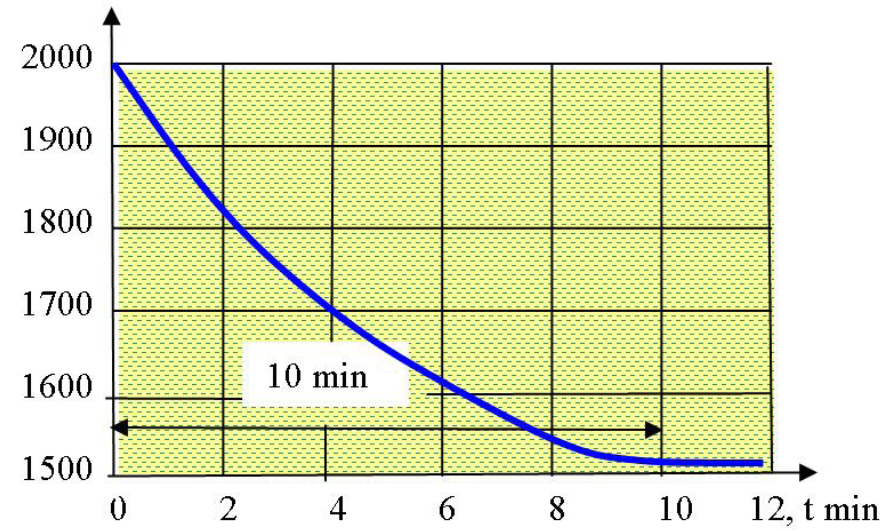

Figure 7. COD reduction graph by chromium-containing stream oxidation (averaged data) (2nd stage)

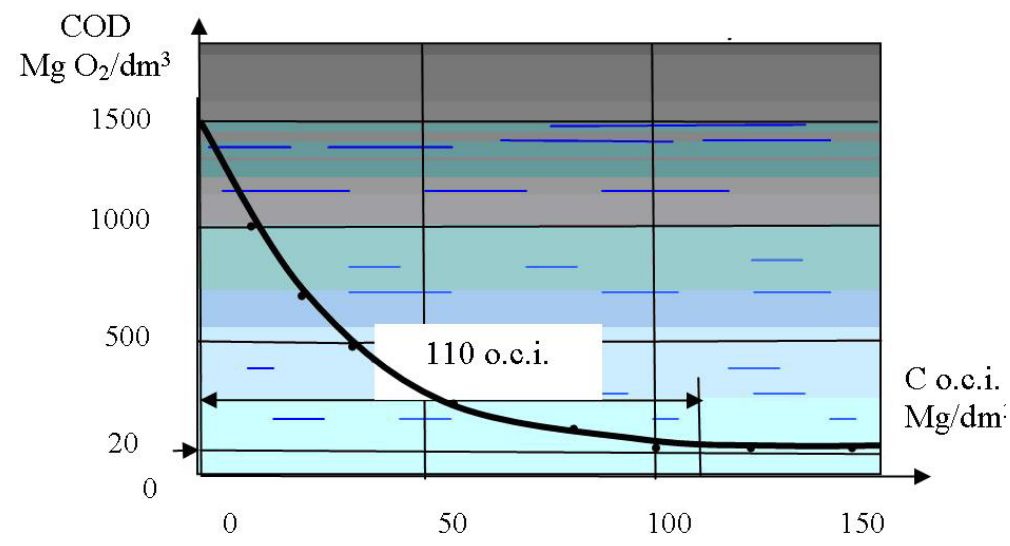

Figure 8. Schedule of COD decrease, sorption by oxyhydrate collector followed by 2-hour sedimentation (averaged data) (stage 3).

* o.c.i - oxyhydrate collector ions 
reducing agent $\mathrm{Fe}$ (II). The block diagram of the technology of wastewater from paint and varnish materials is shown in Figure 9.

Further, this mixture of wastewater is fed into the reactor by a reducing agent $\mathrm{Cr}$ (VI). Maintaining in it $\mathrm{pH}=2-3$ is carried out by acid waste technological solu- tions etching of ferrous metals containing up to $90 \% \mathrm{Fe}$ (II), the rest is $\mathrm{Fe}$ (III). In this case, $\mathrm{Cr}(\mathrm{VI})$ is reduced to $\mathrm{Cr}$ (III), as well as the destruction of organic contaminants by dichromates and catalyzing this process with the traditional chromium catalyst. The time of sewage treatment is up to 10 minutes.

\begin{tabular}{|c|c|c|c|}
\hline № & Scheme, streams, reagents & $\begin{array}{l}\text { Stages of } \\
\text { the process }\end{array}$ & $\begin{array}{l}\text { Time of } \\
\text { processing, } \\
\text { mines }\end{array}$ \\
\hline 1 & $\begin{array}{l}\text { Sinks containing } \\
\text { paintwork } \\
\text { Storage device } \\
\text { Compressed air }\end{array}$ & $\begin{array}{l}\text { Accumulati } \\
\text { on drains } \\
\text { with } \\
\text { paintwork }\end{array}$ & $\begin{array}{l}\text { Purge of } \\
\text { sewage } \\
\text { sludge air } \\
\text { is not less } \\
\text { than } \\
20 \text { minutes }\end{array}$ \\
\hline 2 & $\begin{array}{l}\text { Chromine- } \\
\text { containing effluent } \\
\text { (more than } 1 \\
\text { volume) } \\
\text { Waste acidic } \\
\text { effluents } \\
\text { containing Fe }\end{array}$ & $\begin{array}{l}\text { Mixing of } \\
\text { drains with } \\
\text { LMC in } \\
\text { chrome }\end{array}$ & $\begin{array}{l}\text { Averaging, } \\
\text { at least } 10 \\
\text { minutes }\end{array}$ \\
\hline 3 & $\begin{array}{l}\text { Pickling solution, } \\
\text { acid } \\
\text { Acid-alkaline and } \\
\text { other effluents- }\end{array}$ & $\begin{array}{l}\text { Recovery of } \\
\mathrm{Cr}^{6+} \text { in a } \\
\text { combined } \\
\text { flow with } \\
\text { paintwork } \\
\mathrm{pH}=2 \cdot 0-3.0\end{array}$ & $7-10 \mathrm{~min}$ \\
\hline 4 & $\begin{array}{l}\text { Alkaline waste } \\
\text { technological } \\
\text { solutions, lime } \\
\text { solution }\end{array}$ & $\begin{array}{l}\text { Neutralization } \\
\text { all types of } \\
\text { effluents } \\
\mathrm{pH}=8-9.0\end{array}$ & $7-10 \mathrm{~min}$ \\
\hline 5 & $\leftarrow \frac{1}{2}$ & Lightening & $\begin{array}{l}\text { The time } \\
\text { interval, } \\
\text { depending on } \\
\text { the type of } \\
\text { clarifier }\end{array}$ \\
\hline
\end{tabular}

Figure 9. Simplified scheme of "co-ordinated" decontamination of wastewater contaminated with paintwork materials in the framework of sewage treatment plants of galvanic production of reagent type 
Table 1. Interval of contamination after cleaning

\begin{tabular}{|c|c|c|c|c|c|}
\hline \multirow[t]{2}{*}{ No. } & \multirow[t]{2}{*}{ Ingredient name } & \multirow{2}{*}{$\begin{array}{c}\text { unit of } \\
\text { measurement }\end{array}$} & \multirow{2}{*}{$\begin{array}{l}\text { The average. confidence interval of } \\
\text { concentrations after the neutralizer } \\
\text { reactor }\end{array}$} & \multicolumn{2}{|c|}{$\begin{array}{c}\text { Observed maximum before and after } \\
\text { the vertical settler }\end{array}$} \\
\hline & & & & before & after \\
\hline 1 & Chromium (VI) & $\mathrm{mg} / \mathrm{I}$ & - & - & - \\
\hline 2 & Chromium Society. & $\mathrm{mg} / \mathrm{l}$ & $10-20$ & not spec. & 1.7 \\
\hline 3 & $\mathrm{Zn}$ & $\mathrm{mg} / \mathrm{l}$ & $15-28$ & 32.1 & 0.2 \\
\hline 4 & $\mathrm{Ni}$ & $\mathrm{mg} / \mathrm{l}$ & $2.2-4.9$ & 5.20 & 0.1 \\
\hline 5 & $\mathrm{Fe}$ & $\mathrm{mg} / \mathrm{l}$ & $70-195$ & 250 & 1.5 \\
\hline 6 & $\mathrm{Cu}$ & $\mathrm{mg} / \mathrm{I}$ & $11-22$ & 28.0 & 0.5 \\
\hline 7 & Acid & mg-eq / I & $7.9-9.1$ & 10.8 & - \\
\hline 8 & Alkali & mg-eq / I & $3-4.2$ & 5.25 & - \\
\hline 9 & $\mathrm{pH}$ & & not spec. & not spec. & 8.6 \\
\hline 10 & COD & $\mathrm{mg} / \mathrm{l}$ & $1500-2000$ & 2500 & 21.6 \\
\hline \multicolumn{5}{|c|}{ Total content of main ingredients ( $\mathrm{Fe}_{\text {общ. }} \mathrm{Cr}_{\text {общ. }} \mathrm{Cu} . . \mathrm{Zn}$. Ni) forming a hydroxyhydrate reservoir } & $108.2-269.9$ \\
\hline
\end{tabular}

Following this stage of treatment, the waste liquid is directed to a joint neutralization with other kinds of wastewater to the reactor-neutralizer.

In this reactor, with the aid of neutralizing solutions (alkaline waste technological solutions, and in their absence, the lime solution of $\mathrm{Ca}(\mathrm{OH})_{2}$ is maintained at $\left.\mathrm{pH}=8.0-9.0\right)$. It carries out the hydrolysis of heavy metals $\left(\mathrm{Fe}^{2+}, \mathrm{Fe}^{3+}\right.$, $\mathrm{Zn}^{2+}, \mathrm{Ni}^{2+}, \mathrm{Cr}^{3+}, \mathrm{Cu}^{2+}$, etc.) present in the neutralized mixture to form the oxyhydrate collector, while the hydroxide of $\mathrm{Fe}$ (II) and $\mathrm{Fe}$ (III) are the main components of the oxyhydrate collector on which the paint and other organic contaminants are effectively sorbed.

Further reduction in the concentration of paint and varnish compounds takes place in the clarifier (step 5), resulting from the co-precipitation of suspensions. The efficiency of wastewater treatment is shown in Table 1.

The introduction of "passing" technology of sewage treatment containing paint materials was carried out at the treatment plants of the Brest Electromechanical Plant (BEMZ) on the previously installed equipment for the treatment of waste water from the galvanic production

\section{CONCLUSIONS}

On the basis of the experimental research results, a resource-saving technology for joint wastewater purification of paint and varnish and galvanic productions for instrumentation and machine-building at the existing reagent wastewater treatment plants of the BEMZ galvanic production was developed and implemented [Gurinovich et al. 2014].
The technology allows:

1. A 3-5-fold increase in the capacity of existing technological equipment of galvanic treatment plants, to which polluted waste water is discharged, with a corresponding decrease in their material consumption and energy consumption without reducing the efficiency of wastewater treatment.

2. Due to the use of waste technological solutions instead of purchased reagents, to achieve savings no lesser than $80 \%$.

3. Measure the depth of cleaning in the hydrotipers of the spraying chamber waste water discharged from the baths, at the outlet of the treatment plant for COD from $2500 \mathrm{mg} / 1 \mathrm{O}_{2}$ to $20-15 \mathrm{mg} / 1 \mathrm{O}_{2}$, which is much lower than the value of this indicator $\left(250 \mathrm{mg} / \mathrm{l} \mathrm{O}_{2}\right)$ brought by the controlling companies to the instrument and machine building enterprises in Brest.

4. Utilize the sewage sludge of galvanic production, contaminated with paintwork, in the production of ceramic materials. The environmental safety of the products obtained was confirmed by the Belarusian Scientific Research Institute of Sanitation and Hygiene.

\section{REFERENCES}

1. Gogina E.S., Gurinovich A.D., Urecky E.A. 2012. Resource-saving technologies of industrial water supply and water disposal. ASB, Moscow.

2. Grinin A.S. 2002. Industrial and household waste. Fair-Press, Moscow.

3. Maroz U.V., Urecky E.A. 2013. Studies of the kinetics of processes of sorption of organic impuri- 
ties on oxyhydrate reservoirs and their aggregation in a mixture of paint-containing and galvanic drains. Bulletin of the Belarusian State Technical University, 2(80), 54-57.

4. Maroz U.V. 2014. Resource-saving technology of wastewater treatment of paint and varnish production in instrumentation and engineering. Bulletin of the Belarusian State Technical University, 2(86), 78-81.

5. Subotkin L.D. 2017. Development and implementation of resource-saving technology for joint sew- age treatment of galvanic and paint production. Construction and technogenic security. - Simferopol, 7(59).

6. Tishin O.A. 2002. Determination of the conditions providing the distribution of the residence time in apparatuses with mixers. Izvestiya VUZov, 45, 57-73.

7. Vinogradov S.S. 2002. Organization of galvanic production. Equipment, calculation of production, rationing. Globe, Moscow. 